EduHumaniora: Jurnal Pendidikan Dasar | p-ISSN 2085-1243

Vol. 8. No.1 Januari 2016 | Hal 22-33

\title{
DESAIN DIDAKTIS PADA KONSEP LUAS DAERAH TRAPESIUM UNTUK KELAS V SEKOLAH DASAR
}

\author{
Edya Kresna Annizar', Didi Suryadi \\ Program Studi Pendidikan Dasar S2 Sekolah Pascasarjana UPI Bandung
}

\begin{abstract}
This research was conducted in grade V, Cijambe Elementary School, Cibeber District, Cianjur regency, by using a qualitative approach through the method of Didactical Design Research $(D D R)$. From the results of the initial study, the obstacles found to indicate the presence of ontological obstacles, didactical obstacles, and epistemological obstacles in learning trapezoid. The focus of the analysis is based on the theory of didactic situations, and the results of this analysis are used for the development of a didactic design hypothetic. Hypothetical didactic design is implemented to see how the didactic situations that developed during the learning followed by an analysis of the video transcript of learning outcomes of the implementation. The implementation results are analyzed again to obtain empirical didactic design, called retrosfektif analysis. Empirical didactic design composed of three lesson design. The first lesson design, consisting of three situations in which an action situation and formulations. Lesson second design, consisting of two situations in which an action situation, formulation and validation. Lesson third design, consisting of four situations are situations of action, the situation formulation, validation situation, and the situation institutionalization.
\end{abstract}

Keywords: Didactical Design Research, Learning Obstacle, Didactical Design, Trapezoid.

Abstrak: Penelitian ini dilaksanakan di Kelas V Sekolah Dasar Negeri Cijambe Kecamatan Cibeber Kabupaten Cianjur dengan menggunakan pendekatan kualitatif melalui metode DDR (Didactical Design Research). Dari hasil studi awal, hambatan yang ditemukan menunjukkan adanya ontogenical obstacles, didactical obstacles, dan epistemological obstacles pada pembelajaran trapesium. Fokus analisis berdasarkan teori situasi didaktis, dan hasil analisis ini digunakan untuk pengembangan desain didaktis hipotetik. Desain didaktis hipotetik diimplementasikan untuk melihat bagaimana situasi-situasi didaktis yang berkembang selama pembelajaran dilanjutkan dengan analisis terhadap transkrip video pembelajaran hasil implementasi. Hasil implementasi dianalisis lagi untuk mendapatkan desain didaktis empirik, yang disebut analisis retrosfektif. Desain didaktis empirik yang tersusun terdiri dari tiga pertemuan (lesson design). Lesson design pertama, terdiri dari tiga situasi yang merupakan situasi aksi dan formulasi. Lesson design kedua, terdiri dari dua situasi yang merupakan situasi aksi, formulasi, dan validasi. Lesson design ketiga, terdiri dari empat situasi yang merupakan situasi aksi, situasi formulasi, situasi validasi, dan situasi institusionalisasi.

Kata kunci: Didactical Design Research, Learning Obstacle, Desain Didaktis, Trapesium

\section{PENDAHULUAN}

Pembelajaran merupakan proses penting dalam pendidikan. Menurut Nurdin (2011, hal. 2) seyogianya memperhatikan tahapan kemampuan peserta didik dalam menyerap materi ajar. Salah satu mata pelajaran yang diberikan di Sekolah Dasar sampai Menengah Atas adalah matematika. Proses belajar matematika pada hakekatnya dapat dipandang sebagai suatu proses pembentukan obyek-obyek mental baru yang didasarkan atas proses pengaitan antar obyek mental yang sudah dimiliki sebelumnya (Suryadi, Yulianti, dan Junaeti, 2011).

Fakta empiris yang ditemukan peneliti di kelas V SD Negeri Cijambe Kecamatan Cibeber khususnya dalam materi luas daerah bangun datar, siswa kadang-kadang kebingungan dalam menyelesaikan soal yang berhubungan dengan luas trapesium. Hal ini disebabkan karena pola pembelajaran yang diterapkan

\footnotetext{
${ }^{1}$ Mahasiswa S2 Pendas SPs UPI Bandung, Email: kresnaannizar@yahoo.co.id

2 Dosen Universitas Pendidikan Indonesia
} 
dalam materi luas daerah bangun datar sebelumnya langsung menghafalkan rumus, adapun permasalahan yang dihadapi siswa adalah sulitnya menentukan luas daerah trapesium, sering tertukarnya dalam penggunaan rumus tersebut. Ketika dihadapkan dengan bentuk trapesium yang konteksnya berbeda maka siswa akan mengalami kesulitan.

Dalam menghadapi berbagai hambatan belajar (learning obstacle) tersebut, maka sebagai seorang guru harus memiliki kompetensi secara didaktik dan konseptual, dengan demikian perlu adanya suatu proses perencanaan pembelajaran (Desain Didaktis) yang merupakan langkah awal sebelum adanya pembelajaran dengan memperhatikan tahapan-tahapan pembelajaran yang disebut Hypothetical Learning Trajectory (Simon, 1995; dan Clements dan Sarama, 2009). Berdasarkan latar belakang yang telah dipaparkan di atas peneliti mengambil judul: "Desain Didaktis Pada Konsep Luas Daerah Trapesium untuk Kelas V Sekolah Dasar".

\section{TINJAUAN TEORITIS}

Desain didaktis merupakan rancangan bahan ajar yang disusun berdasarkan penelitian learning obstacle suatu materi pembelajaran dengan harapan dapat mengurangi kesulitan yang dialami siswa dalam pembelajaran sehingga tujuan pembelajaran terpenuhi. Penelitian desain didaktis pada dasarnya terdiri atas tiga tahapan yaitu: (1) analisis situasi didaktis sebelum pembelajaran berupa desain didaktis hipotetik termasuk Antisipasi Didaktis Pedagogis (ADP), (2) analisis metapedadidaktik, dan (3) analisis retrosfektif yakni analisis yang mengaitkan hasil analisis situasi didaktis hipotetik dengan hasil analisis metapedadidaktik (Suryadi, 2010).

Hubungan antara guru, peserta didik dan materi ajar digambarkan oleh Kansanen (2003) sebagai sebuah Segitiga
Didaktis yang menggambarkan hubungan didaktis (HD) antara peserta didik dan materi, dan hubungan pedagogis (HP) antara guru dan peserta didik. Menurut Suryadi (2010), Ilustrasi kansanen belum menggambarkan hubungan guru-materi sehingga akan memunculkan situasi yang baru yang tidak diantisipasi sebelumnya oleh guru. Kedua hal tersebut (didaktis pedagogis) tidak dapat dipandang secara parsial namun harus dipahami secara utuh, karenanya guru perlu merancang situasi didaktis dan pedagogis, serta merancang antisipasi respon peserta didik yang akan muncul ketika proses pembelajaran berlangsung sehingga akan memunculkan situasi didaktis baru. Atau dapat digambarkan sebagai berikut:

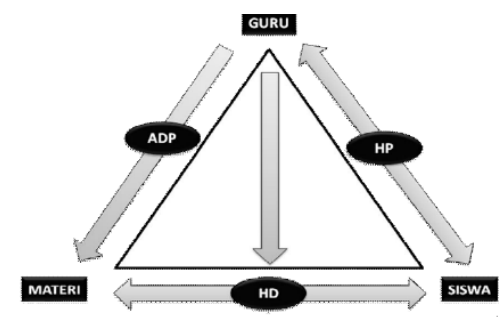

Gambar 1. Segitiga Didaktis yang Dimodifikasi

Berdasarkan segitiga tersebut, Guru harus memahami bahan ajar dan pengetahuan lain yang terkait dengan peserta didik serta mampu menciptakan situasi didaktis yang dapat mendorong proses belajar secara optimal (Suryadi, 2013). Walhasil, seorang guru perlu memiliki kemampuan untuk menciptakan relasi didaktis (didactical relation) antara peserta didik dan materi ajar sehingga tercipta suatu situasi didaktis ideal bagi peserta didik. Hal ini dilakukan untuk mengantisipasi munculnya hambatan belajar(learning obstacle) dalam diri peserta didik ketika proses pembelajaran berlangsung.

Kemampuan yang perlu dimiliki guru tersebut, selanjutnya akan disebut sebagai metapedadidaktik yang dapat diartikan sebagai kemampuan guru untuk: 
1. Memandang komponen-komponen segitiga didaktis yang dimodifikasi yaitu ADP, HD, HP sebagai suatu kesatuan yang utuh,

2. Mengembangkan tindakan sehingga tercipta situasi didaktis dan pedagogis yang sesuai dengan kebutuhan peserta didik,

3. Mengidentifikasi serta menganalisis respon peserta didik sebagai akibat tindakan didaktis maupun pedagogis yang dilakukan, dan

4. Melakukan tindakan didaktis dan pedagogis lanjutan berdasarkan hasil analisis respon peserta didik menuju pencapaian target pembelajaran.

Metapedadidaktik memiliki tiga komponen yang terintegrasi satu sama lainnya, yaitu kesatuan, fleksibilitas, dan koherensi (Suryadi, 2010, hal. 8).

Pengetahuan ilmiah seorang siswa yang sedang belajar didapat dari hasil aksinya melalui formulasi dan validasi yang menuju pada institusionalisasi. Tahapan ini disebut situasi didaktis, menurut Brousseau (2002) dan Manno (2006) tahapan ini terbagi ke dalam empat situasi, yaitu: "situasi aksi, situasi formulasi, situasi validasi, dan situasi institusionalisasi”.

Matematika merupakan ilmu yang mempunyai beberapa karakteristik diantaranya objek matematika tidaklah kongkrit tetapi abstrak. Matematika itu timbul karena fikiran-fikiran manusia yang berhubungan dengan ide, proses, dan penalaran. Untuk menjembatani menuju ke arah abstrak tersebut maka diperlukan suatu proses yang disebut abstraksi.

Trapesium merupakan salah satu bangun datar yang dipelajari dalam geometri di kelas $\mathrm{V}$ sekolah dasar. Menurut Weisstein (2003, hal. 4019) dalam bukunya yang berjudul CRC Concise Ensyclopedia Mathematics menyatakan bahwa: "Square it means convex quadrilateral with four equal sides at right angles to each other".
Trapezium are two common definitions of the trapezium. The American definitions is a quadrilateral with no paralel sides. The British definitions for a trapezium is a quadrilateral with two sides parallel. Such a trapezium is equivalent to a trapezoid and therefore has area $A$ $=\frac{1}{2}(a+b) h$.

\section{METODOLOGI PENELITIAN}

Penelitian ini menggunakan pendekatan kualitatif dengan metode DDR (Didactical Design Research). DDR adalah penelitian yang mengungkap hambatan belajar (learning obstacle) dalam proses pembelajaran dan bertujuan untuk mengantisipasi dan menghilangkan hambatan belajar dalam pembelajaran (Suryadi, 2010). Fokus penelitian ini adalah mengembangkan desain didaktis luas daerah trapesium di kelas V sekolah dasar.

Penelitian DDR (didactical Design Research) ini dilakukan di SD Negeri Cijambe Kecamatan Cibeber Kabupaten Cianjur yang beralamat di Kp. Cijambe Desa Sukamaju Kecamatan Cibeber Kabupaten Cianjur. Subjek penelitiannya adalah siswa kelas $\mathrm{V}$ yang merupakan tempat uji coba berupa implementasi desain didaktis hipotetik.

Data yang dikumpulkan dalam penelitian ini adalah gambaran desain didaktis luas daerah trapesium yang digunakan siswa selama ini. Data ini diperoleh dari analisis bahan ajar yang digunakan siswa dan kesulitan belajar siswa mengenai luas daerah trapesium. Kedua, data tentang luas daerah trapesium dilihat dari perspektif teoritis, diperoleh dari analisis secara teoritis dan kajian repersonalisasi peneliti yang merupakan penelusuran terhadap artikel/jurnal yang relevan. Ketiga, data hasil implementasi desain, diperoleh melalui observasi selama implementasi dan transkrip video 
pembelajaran pada saat implementasi desain.

Pengumpulan data dalam penelitian ini dilakukan dengan triangulasi yang merupakan teknik pengumpulan data yang bersifat menggabungkan dari berbagai teknik pengumpulan data dan sumber data yang telah ada (Sugiyono, 2013). Apabila peneliti melakukan pengumpulan data dengan triangulasi, maka sebenarnya peneliti mengumpulkan data yang sekaligus menguji kredibilitas data, yaitu mengecek kredibilitas data dengan berbagai teknik pengumpulan data dan berbagai sumber data. Triangulasi yang digunakan dalam penelitian ini merupakan triangulasi sumber dan triangulasi teknik berupa observasi, wawancara, dan dokumentasi.

Data yang dianalisis dalam penelitian ini adalah data desain didaktis awal yang diperoleh dari data hasil ujicoba desain didaktis hipotetik dan transkrip video pembelajaran. Model analisis data yang digunakan adalah model analisis data kualitatif menurut Miles dan Hubarmen (dalam Sugiyono, 2013). Analisis data dilakukan menurut tahaptahap berikut ini:

1. Pengumpulan Data

2. Penyajian Data

3. Penarikan Kesimpulan

Prosedur yang dilakukan dalam penelitian ini adalah:

1. Menganalisis bahan ajar yang digunakan siswa, menganalisis perangkat pembelajaran yang biasa digunakan guru, dan menganalisis kesulitan belajar (learning obstacles) siswa dalam pembelajaran luas daerah trapesium;

2. Melakukan studi literatur (penelusuran terhadap artikel/jurnal yang relevan);

3. Melakukan repersonalisasi, yaitu pengkajian lebih mendalam terhadap materi ajar yang akan diteliti;

4. Merancang desain didaktis hipotetik termasuk Antisipasi Didaktis Pedagogis (ADP);
5. Mengkonsultasikan desain didaktis hipotetik kepada pembimbing,

6. Mengujicobakan desain didaktis hipotetik;

7. Menganalisis hasil ujicoba (hasil observasi selama implementasi dan transkrip video pembelajaran); dan

8. Menyusun desain didaktis empirik.

\section{HASIL PENELITIAN DAN PEMBAHASAN}

Hasil penelitian yang akan disajikan diantaranya mencakup learning obstacles luas daerah trapesium, desain didaktis awal, analisis implementasi desain dan desain didaktis empirik.

Berdasarkan hasil analisis jawaban siswa, dari jumlah siswa 18 orang terdapat 15 orang siswa yang mengalami learning obstacles, baik itu ontogenical obstacles, didactical obstacles, maupun epistemological obstacles. Dengan demikian diperlukan antisipasi didaktis untuk mengatasi learning obstacles tersebut. Selain analisis terhadap hasil studi awal, peneliti juga menganalisis bahan ajar dan perangkat pembelajaran seperti RPP dan LKS yang biasa digunakan dalam pembelajaran seharihari. Setelah dianalisis ternyata RPP tentang trapesium yang biasa digunakan tidak terperinci, tidak memperhatikan respon peserta didik, dan tidak mengantisipasi hasil prediksi respon peserta didik.

\section{Desain Didaktis Awal (Preliminary}

Didactical Design)

Lesson Design Kesatu

Situasi Belajar 1: Mengidentifikasi

Benda-Benda di Sekitar yang berbentuk Trapesium

Tujuan Pembelajaran:

Melalui pengamatan terhadap gambar dan benda di sekitar sekolah, siswa dapat mengidentifikasi benda-benda yang berbentuk trapesium dengan benar.

Prediksi respon pemikiran siswa pada situasi belajar 1 adalah sebagai berikut: 
1. Siswa dapat menyebutkan nama-nama bangun datar yang sudah diketahui

2. Siswa dapat menyebutkan nama benda di dalam kelas yang berbentuk bangun datar tertentu

3. Siswa menuliskan berbagai benda di luar kelas meskipun permukaannya tidak datar

4. Ada siswa yang mungkin sudah mengetahui model trapesium

5. Siswa menyebutkan contoh benda lain yang berbentuk trapesium selain yang dicontohkan guru

Antisipasi didaktis berdasarkan prediksi respon siswa di atas adalah jika siswa akan mempelajari luas daerah trapesium maka harus menguasai konsep prasyaratnya. Konsep prasyaratnya yaitu harus menguasai konsep dan luas bangun datar persegi panjang serta segitiga. Prasyarat ini nantinya akan menjadi tempat berkaitnya pengetahuan baru yaitu luas trapesium. Antisipasi kedua apabila siswa menuliskan permukaan benda meskipun tidak datar, maka guru membatasi/menegaskan kembali bahwa yang dituliskan hanya yang permukaannya datar saja. Terakhir jika ada siswa yang sudah mengetahui bentuk trapesium maka diadakan konfirmasi sampai sejauh mana pemahamannya.

Situasi Belajar 2: Mengidentifikasi ciriciri bangun datar trapesium

Tujuan:

Melalui pengamatan dan manipulasi terhadap model trapesium, siswa dapat mengidentifikasi ciri-ciri bangun datar trapesium dengan benar.

Prediksi respon pemikiran siswa pada situasi belajar 2 adalah sebagai berikut:

1. Siswa tidak dapat mengidentifikasi sisi sejajar dalam trapesium

2. Siswa dapat mengidentifikasi ciri-ciri bangun datar trapesium.

Antisipasi didaktis berdasarkan prediksi respon siswa di atas adalah dengan mempertegas konsep kesejajaran melalui contoh dalam sehari-hari seperti rel kereta api dan sebagainya. Antisipasi kedua jika siswa dapat mengidentifikasi ciri-ciri bangun datar trapesium, guru dapat membuat konfirmasi dengan cara memberikan pertanyaan lanjutan mengenai ciri-ciri bangun datar trapesium agar siswa lebih mantap pemahamannya.

Situasi Belajar 3: Mengklasifikasikan bangun datar trapesium dan bangun datar lainnya

Tujuan:

Siswa dapat Mengklasifikasikan bangun datar trapesium dan bangun datar lainnya dengan tepat.

Prediksi respon pemikiran siswa pada situasi 3 adalah sebagai berikut:

1. Siswa dapat mengklasifikasikan bangun datar sesuai namanya

2. Siswa tertukar dalam mengklasifikasikan trapesium dengan bangun datar lain

3. Siswa kesulitan mengkomunikasikan hasil temuannya di depan kelas

Antisipasi didaktis berdasarkan prediksi respon siswa di atas adalah dengan cara mengingatkan kembali pada definisi masing-masing bangun datar tersebut kemudian apabila siswa mengalami kesulitan mengkomunikasikan hasil temuannya di depan kelas guru sedikit mengarahkan penggunaan kalimatnya agar sesuai dengan kaidah/tata bahasa yang baku/biasa digunakan.

\section{Lesson Design Kedua}

Situasi Belajar 1: Menentukan sisi sejajar dan tinggi pada trapesium

Tujuan:

Melalui pengamatan terhadap gambar trapesium dan manipulasi terhadap model trapesium, siswa dapat menentukan sisi sejajar pada bangun datar trapesium dengan benar.

Prediksi respon pemikiran siswa pada situasi belajar 1 adalah sebagai berikut:

1. Siswa dapat menentukan sisi sejajar dan tinggi pada trapesium dengan tepat

2. Siswa keliru dalam menentukan sisi sejajar dan tinggi pada trapesium 
3. Siswa tidak menguasai konsep kesejajaran

Antisipasi didaktis berdasarkan prediksi respon siswa di atas adalah dengan cara:

1. Pemberian apresiasi bagi siswa yang sudah mampu menentukan sisi sejajar dan tinggi pada trapesium. Hal ini dimaksudkan agar memberi rasa bangga sehingga lebih bersemangat lagi belajarnya, selain itu sebagai motivasi bagi mereka yang belum mampu menentukannya.

2. Apabila menemukan siswa yang masih keliru dalam menentukan sisi sejajar dan tinggi pada trapesium maka antisipasi yang dilakukan guru adalah dengan menginstruksikan agar memutar kertasnya sehingga didapati gambar trapesium seperti yang biasa dilihat (sisi sejajarnya horizontal), kemudian membuat garis tegak lurus di antara kedua sisi sejajar tersebut sebagai tingginya.

\section{Situasi Belajar 2: Mengklasifikasikan Jenis-Jenis Trapesium}

Tujuan: Melalui diskusi siswa dapat mengklasifikasikan bangun datar trapesium sama kaki, siku-siku, dan sembarang dengan tepat.

Prediksi respon pemikiran siswa pada situasi belajar 2 adalah sebagai berikut:

1. Siswa dapat mengklasifikasikan trapesium sesuai namanya,

2. Siswa tertukar dalam mengklasifikasikan trapesium,

3. Siswa tidak dapat membedakan antara trapesium sembarang dengan trapesium sama kaki.

Antisipasi didaktis berdasarkan prediksi respon siswa di atas adalah dengan cara:

1. Pemberian apresiasi bagi siswa yang sudah mampu mengklasifikasikan trapesium sesuai namanya. Hal ini dimaksudkan agar memberi rasa bangga sehingga lebih bersemangat lagi belajarnya, selain itu sebagai motivasi bagi mereka yang belum mampu mengklasifikasikannya
2. Bagi siswa yang masih keliru dalam mengklasifikasikannya, entah itu tertukar atau tidak dapat membedakan antara trapesium sembarang dengan trapesium sama kaki, guru memberi scaffolding dengan cara membimbingnya mengidentifikasi ketiga jenis trapesium. Salah satunya dengan mengukur panjang kaki masing-masing trapesium dan mengukur salah satu sudutnya.

\section{Lesson Design Ketiga}

Situasi Belajar 1: Menentukan luas daerah trapesium dengan pendekatan persegi panjang.

Tujuan

Melalui unjuk kerja siswa dapat menentukan luas daerah trapesium dengan pendekatan persegi panjang dengan tepat. Media yang digunakan adalah kertas berpetak, gunting dan lem.

Prediksi respon pemikiran siswa pada situasi belajar 1 adalah sebagai berikut:

1. Siswa dapat menentukan luas daerah trapesium dengan pendekatan persegi panjang dengan tepat

2. Siswa kebingungan dalam mengimpitkan kedua gambar trapesium

3. Siswa tidak dapat menyimpulkan bahwa trapesium merupakan setengahnya dari persegi panjang yang diperoleh

Antisipasi didaktis berdasarkan prediksi respon siswa di atas adalah dengan cara:

1. Pemberian apresiasi bagi siswa yang sudah mampu menentukan luas trapesium melalui pendekatan persegi panjang. Hal ini dimaksudkan agar memberi rasa bangga sehingga lebih bersemangat lagi belajarnya, selain itu sebagai motivasi bagi mereka yang belum mampu menentukannya.

2. Membantu siswa mengimpitkan kedua gambar trapesium namun ide pokoknya diharapkan muncul dari siswanya sendiri, guru hanya mengarahkan kira- 
kira kalau digabungkan menjadi bangun apa dan sebagainya.

3. Apabila muncul prediksi ketiga yaitu siswa tidak dapat menyimpulkan bahwa trapesium merupakan setengahnya dari persegi panjang yang diperoleh, maka kedua trapesium itu dipecah lagi menjadi dua kemudian memperjelas lagi kalau satu bagian dari dua trapesium itu merupakan setengahnya.

Situasi Belajar 2: Menentukan luas daerah trapesium dengan pendekatan segitiga.

Tujuan

Melalui unjuk kerja siswa dapat menentukan luas daerah trapesium dengan pendekatan segitiga dengan tepat.

Media yang digunakan adalah kertas berpetak, gunting dan lem.

Adapun prediksi respon pemikiran siswa pada situasi belajar 2 adalah sebagai berikut:

1. Siswa dapat membagi trapesium menjadi dua buah segitiga dengan alasnya adalah sisi-sisi sejajar pada trapesium

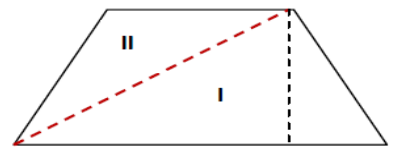

2. Siswa membagi trapesium menjadi satu buah persegi panjang dan dua buah segitiga

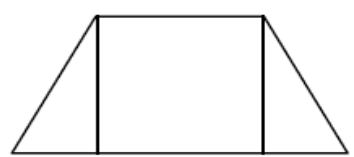

3. Siswa nanya mengnıtung ıuas segitiga atau luas persegi panjang saja sehingga tidak sampai kepada luas trapesium.

Antisipasi didaktis berdasarkan prediksi respon siswa di atas adalah dengan cara:

1. Pemberian apresiasi bagi siswa yang sudah mampu menentukan luas trapesium melalui pendekatan segitiga. Hal ini dimaksudkan agar memberi rasa bangga sehingga lebih bersemangat lagi belajarnya, selain itu sebagai motivasi bagi mereka yang belum mampu menentukannya.

2. Apabila siswa hanya menghitung luas segitiga atau luas persegi panjang saja, maka antisipasi yang dilakukan adalah mengingatkan kembali kepada siswa bahwa trapesium itu merupakan gabungan dari kedua segitiga tersebut sehingga harus dijumlahkan kedua luas segitiga tersebut.

\section{Situasi Belajar 3: Menggunakan rumus luas daerah trapesium dalam perhitungan}

Tujuan:

Siswa dapat menggunakan rumus luas trapesium dalam perhitungan dengan tepat.

Media yang digunakan di antaranya adalah: halaman sekolah, tali rapia, meteran.

Adapun prediksi respon pemikiran siswa pada situasi belajar 3 ini adalah sebagai berikut:

1. Siswa dapat mengukur dan menghitung luas permukaan tanah yang berbentuk trapesium dengan tepat

2. Siswa mengukur semua sisi dari permukaan tanah yang dibatasi tali rapia

3. Siswa kesulitan dalam menggambarkan hasil pengukurannya ke dalam kertas HVS atau buku catatan.

Antisipasi didaktis berdasarkan prediksi respon siswa di atas adalah dengan cara:

1. Pemberian apresiasi bagi siswa yang sudah mampu menghitung luas trapesium. Hal ini dimaksudkan agar memberi rasa bangga sehingga lebih bersemangat lagi belajarnya, selain itu sebagai motivasi bagi mereka yang belum mampu melakukannya.

2. Apabila prediksi respon kedua muncul, yaitu siswa mengukur semua sisi dari permukaan tanah yang dibatasi tali rapia maka guru mengingatkan kembali bahwa yang harus diketahui 
ukurannya hanyalah sisi sejajar dan tingginya saja.

3. Apabila prediksi respon ketiga muncul, yaitu siswa kesulitan dalam menggambarkan hasil pengukurannya ke dalam kertas HVS atau buku catatan maka langkah yang dilakukan adalah membimbing siswa tersebut dengan mengajak berdiri di depan permukaan tanah yang dibatasi rapia kemudian perhatikan satu-satu sisi masingmasing dan membuat garis setiap tali rapia membentang.

\section{Analisis Retrosfektif (Analisis Implementasi Desain Didaktis)}

Setelah diimplementasikan desain didaktis yang sudah disusun ternyata masih ada ketidaksesuaian antara harapan dan kenyataan. Masih banyak prediksi respon siswa yang tidak tercover, demikian juga antisipasi didaktis yang dirumuskan dirasa masih kurang selama pembelajaran berlangsung.

\section{Lesson Design Satu}

Respon siswa yang masih kesulitan dalam mengidentifikasi bangun datar antara lain sebagai berikut:

1. Seluruh siswa sudah mengetahui hampir semua jenis bangun datar namun masih mengingat namanya saja tanpa menguasai konsepnya.

2. Kesulitan mengidentifikasi ciri-ciri bangun datar trapesium

3. Siswa keliru mengelompokkan jenisjenis bangun datar, belah ketupat disatukan dengan layang-layang, trapesium dianggap jajargenjang.

4. Kesulitan mengkomunikasikan hasil diskusi

Berdasarkan analisis di atas, ada beberapa rekomendasi untuk revisi desain. Pertama, dalam situasi ketiga ini secara umum sudah bagus, perlu dipertahankan karena kegiatannya menarik bagi siswa. Mereka terlihat antusias dalam pengerjaannya, terjadi hands on activity. Kedua, pembuatan model bangun datar harus teliti. Panjang salah satu sisi layang- layang jangan sama dengan sisi belah ketupat dan sebagainya. Ketiga, kesimpulan yang diambil kurang signifikan, harusnya mengarah pada definisi trapesium terlebih dahulu baru pada manfaat dalam kehidupan seharihari.

\section{Lesson Design Dua}

Respon siswa yang masih kesulitan pada lesson design dua ini adalah sebagai berikut:

1. Siswa kesulitan dalam menentukan tinggi trapesium, terutama pada trapesium sama kaki dan trapesium sembarang.

2. Siswa kesulitan menuliskan namanama sisi sejajar dan tinggi pada trapesium.

Berdasarkan temuan di atas sepertinya siswa tersebut mengalami hambatan ontogeni. Hambatan ontogenis adalah hambatan yang disebabkan oleh kesiapan mental belajar peserta didik dalam menghadapi proses pembelajaran yang kurang. Kenyataannya memang diakui, ketika guru menyampaikan konsep tidak memperhatikan keadaan sekeliling siswa apakah mereka sudah siap menerima informasi atau belum sehingga terjadilah miskonsepsi seperti itu.

Berikut ini ada beberapa rekomendasi untuk revisi desain. Pertama, tidak ada masalah yang berarti, semua situasi sesuai prediksi. Desain seperti ini bisa terus dipergunakan. Kedua, untuk masalah teknis pengucapan bisa diantisipasi guru dengan baik yaitu dengan scaffolding berupa penekanan bahwa untuk trapesium siku-siku dan sembarang tidak usah menggunakan kata 'sama'.

\section{Lesson Design Tiga}

Respon siswa yang masih kesulitan pada lesson design tiga ini adalah sebagai berikut:

1. Siswa menggambar trapesium tidak tepat pada garis di kertas berpetaknya. 
2. Siswa kesulitan mengimpitkan dan membentuk sebuah persegi panjang dari dua buah trapesium

3. Siswa kesulitan mengasumsikan sebuah trapesium merupakan setengahnya dari luas persegi panjang.

4. Kesulitan menghitung luas trapesium

5. Siswa mengukur semua sisi dari trapesium

6. Siswa kebingungan mengukur tinggi dari trapesium

Berdasarkan analisis di atas, ada beberapa rekomendasi untuk revisi desain. Pertama, semua instruksi guru harus jelas agar siswa tidak mengulangi kesalahan dalam menentukan tinggi trapesium. Kedua, waktu tidak mencukupi sehingga dalam desain revisi nanti hal-hal yang kurang esensial lebih baik tidak dilakukan seperti pengulangan kata-kata guru dan sebagainya.

\section{Desain Didaktis Empirik}

Desain didaktis empirik yang dimaksud dalam penelitian ini adalah desain didaktis yang sudah mengalami revisi.

\section{Lesson Design Empirik Satu}

Dari hasil analisis retrosfektif pada situasi pertama ternyata diperoleh data seperti berikut ini: 1) seluruh siswa sudah mengetahui hampir semua jenis bangun datar namun masih mengingat namanya saja tanpa menguasai konsepnya, 2) semua siswa belum mengenal bangun datar trapesium, 3) Prediksi respon kelima tidak muncul, yaitu tidak ada siswa yang menyebutkan contoh benda berbentuk trapesium selain yang dicontohkan guru.

Dengan demikian revisi dalam lesson design satu ini adalah sebagai berikut:

Pada situasi 1:

1. Siswa harus betul-betul sudah bisa membedakan antara konsep bangun ruang dengan bangun datar. Prasyarat ini nantinya akan menjadi tempat berkaitnya pengetahuan baru yaitu luas trapesium.
2. Apabila siswa menuliskan permukaan benda meskipun tidak datar, maka guru membatasi/menegaskan kembali bahwa yang dituliskan hanya yang permukaannya datar saja.

3. Jika ada siswa yang sudah mengetahui bentuk trapesium maka diadakan konfirmasi sampai sejauh mana pemahamannya mengenai trapesium tersebut.

4. Situasi harus sampai pada definisi trapesium, yaitu segiempat khusus yang memiliki sepasang sisi sejajar.

5. Guru harus menyajikan model trapesium tiga dimensi selain gambar, seperti meja dan sebagainya agar siswa lebih optimal dalam memanipulasi medianya

Pada situasi 2:

1. Harus ada penekanan pada konsep kesejajaran dalam trapesium

2. Siswa harus sampai bisa pada kegiatan membedakan trapesium dengan bangun datar lainnya.

Pada situasi 3:

1. Secara umum sudah bagus, perlu dipertahankan karena kegiatannya menarik bagi siswa. Mereka terlihat antusias dalam pengerjaannya, terjadi hands on activity.

2. Pembuatan model bangun datar harus teliti seperti panjang salah satu sisi layang-layang jangan sama dengan sisi belah ketupat dan sebagainya.

3. Kesimpulan yang diambil harus signifikan, mengarah pada definisi trapesium terlebih dahulu baru pada manfaat dalam kehidupan sehari-hari.

Berdasarkan teori situasi didaktis, maka pada lesson design satu ini telah terjadi situasi aksi dan situasi formulasi. Situasi pertama telah terjadi situasi aksi, sedangkan situasi kedua dan ketiga terjadi situasi formulasi. Siswa mengalami yang disebut dengan trial dan error dalam menentukan benda yang permukaannya datar sehingga semua benda yang dilihatnya dikategorikan sebagai bangun datar. Skenario pembelajaran pada situasi 
formulasi dikembangkan berdasarkan aktivitas dan pengalaman pada situasi aksi. Siswa membandingkan dan mendiskusikan hasil pekerjaannnya dengan teman yang lain.

\section{Lesson Design Empirik Dua}

Berdasarkan hasil implementasi dan analisis retrosfeksi pada situasi pertama diperoleh data yaitu beberapa siswa menunjuk kaki trapesiumnya sebagai tinggi, demikian juga terjadi pada waktu menunjukkan tinggi pada trapesium sembarang. Hal ini terjadi karena pada pembelajaran sebelumnya guru hanya memberikan contoh tinggi pada trapesium siku-siku atau pada trapesium yang lainnya namun tingginya sudah tersedia yaitu dengan garis terputus-putus tanpa menjelaskan tegak lurusnya. Langkah guru dalam menyikapi respon ini adalah dengan menganalogikan sisi sejajar dengan rel kereta api dan tanda sama dengan yang notabene sering dijumpai dalam keseharian siswa. Dengan demikian dalam desain revisinya adalah guru mempertahankan situasi belajar ini karena kegiatan ini sudah bagus, dapat memunculkan respon siswa yang diprediksi.

Berdasarkan teori situasi didaktis, maka pada lesson design dua ini telah terjadi situasi aksi, situasi formulasi dan situasi validasi. Situasi pertama telah terjadi situasi aksi dan formulasi, di mana siswa mendiskusikan hasil pengamatannya dengan siswa lain. Pengetahuan pada situasi ini tampil sebagai hasil dari pengalaman yang harus dikomunikasikan agar dapat dipahami. Sedangkan pada situasi kedua terjadi situasi aksi, formulasi dan validasi. Hal ini terlihat dengan kegiatan siswa yang melakukan kegiatan mengklasifikasikan trapesium berdasarkan jenisnya (aksi) dan kemampuan siswa dalam menganalisis jenis-jenis trapesium sesuai dengan jenisnya tersebut (formulasi). Guru membimbing siswa yang mengalami kesulitan dalam mengklasifikasikan jenis trapesium (validasi).

\section{Lesson Design Empirik Tiga}

Desain revisi ketiga ini ditekankan pada antisipasi didaktisnya sebagai berikut: langkah pertama, pemberian scaffolding terhadap siswa yang masih salah dalam menggambar trapesium. Kedua, pemberian instruksi yang jelas terhadap setiap langkah kegiatan. Ketiga, guru harus meyakinkan diri bahwa siswa sudah menguasai teknik penghitungan sebelum mencari luas trapesium. Guru seyogianya memperhatikan alur desain yang telah disusun sehingga tidak ada situasi yang terlewat. Pada lesson design tiga ini harus ditambah satu situasi tersendiri untuk kegiatan membagi trapesium menjadi satu buah persegi panjang dan dua buah segitiga sehingga dalam desain ketiga ini menjadi empat situasi.

Semua instruksi guru harus jelas agar siswa tidak mengulangi kesalahan dalam menentukan tinggi trapesium. Waktu yang digunakan tidak mencukupi sehingga dalam desain revisi nanti hal-hal yang kurang esensial lebih baik tidak dilakukan seperti pengulangan kata-kata guru, penjelasan mengenai jenis-jenis trapesium sebelum siswa mengukur di lapangan, dan sebagainya. Harus ditambah satu prediksi respon siswa dalam situasi ketiga ini, yaitu menggunakan rumus luas daerah trapesium dalam perhitungan. Hal ini dimaksudkan untuk mengukur sejauh mana kemampuan siswa dalam memahami dan menggunakan rumus luas trapesium yang telah dikuasainya. Selain itu juga penambahan prediksi respon siswa ini berfungsi sebagai barometer bagi guru untuk mengukur sejauh mana keberhasilan pembelajaran dengan menggunakan desain didaktis ini.

Berdasarkan teori situasi didaktis, maka pada lesson design tiga ini telah terjadi situasi aksi, situasi formulasi, 
situasi validasi dan situasi Institusionalisasi. Berkaitan dengan situasi validasi, pada setiap situasi pembelajaran guru melakukan bimbingan dan arahan agar siswa lebih optimal dalam mengembangkan potensi yang dimilikinya. Hal ini terbukti dengan scaffolding yang diberikan guru pada setiap tahapan dan respon siswa yang masih kurang sesuai dengan prediksi awal.

\section{KESIMPULAN}

1. Desain didaktis dalam penelitian ini didasarkan pada learning obstacles pada materi luas daerah trapesium. Dari hasil studi awal, hambatan yang ditemukan menunjukkan adanya hambatan ontogeni, hambatan didaktis, dan hambatan epistemologis.

2. Analisis retrosfektif pada penelitian ini dilakukan setelah implementasi seluruh desain dilaksanakan. Respon siswa yang diprediksi sebelum pembelajaran pada desain didaktis hipotetik ternyata muncul secara beragam, ada yang sesuai prediksi ada pula yang muncul di luar prediksi. Kesenjangan tersebut dibandingkan dengan hasil analisis metapedadidaktik sehingga proses pembelajaran berlangsung dinamis yang ditandai dengan terintegrasinya antara hubungan guru dengan siswa dan materi ajar kemudian hasilnya dijadikan rekomendasi dalam desain didaktis empirik.

3. Desain didaktis empirik yang tercipta merupakan hasil modifikasi dari desain didaktis hipotetik berdasarkan analisis retrosfektif yang tidak tertutup kemungkinan masih bisa dikembangkan lagi lebih lanjut

\section{DAFTAR PUSTAKA}

Brousseau, G. (2002). Theory of Didactical Situation in Mathematics. Dordrecht: Kluwer Academic Publishers
Clements, D.H. and Sarama, J. (2009). Learning and Teaching Early Math: The Learning Trajectories Approach. New York: Routledge.

Kansanen, P. (2003). StudyingtheRealistic Bridge Between Instruction and Learning. An Attempt to a Conceptual Whole of the Teaching-Studying-Learning Process. Educational Studies, Vol. 29, No. 2/3, 221-232

Manno, G. (2006). Embodiment and ADidactical Situation in The Teaching Learning of the Perpendicular Straight Lines Concept. (Doctoral Thesis, Faculty of Mathematics and Physics Departement of Didactic Mathematics Comenius University Bratislava).

Nurdin. (2011). Trajektori dalam Pembelajaran Matematika. Edumatica, 1(1), hal. 1-7.

Simon, M. A. (1995). Reconstructing Mathematics Pedagogy from a Constructivist Perspective. Journal for Research in Mathematics Education, 26(2), 114-145.

Sugiyono. (2013). Metode Penelitian Pendidikan. Bandung: Alfabeta.

Suryadi, D. (2010). Didactical Design Research (DDR) dalam Pengembangan Pembelajaran Matematika1 (Dipresentasikan dalam Seminar Nasional Pembelajaran MIPA di UM Malang, 13 November 2010). Malang: MIPA

Suryadi, D., Yulianti, K., dan Junaeti, E. (2011). Model Antisipasi Dan Situasi Didaktis Dalam Pembelajaran Matematika 
Kombinatorik Berbasis Pendekatan

Tidak Langsung. Bandung: SPs UPI.

Suryadi, D. (2013). Didactical Design Research (DDR) to Improve the Teaching of Mathematics. Far East Journal of Mathematical Education. Volume 10, Number 1, 2013, pages
91-107. Published online: January 2013. Available online at http://pphmj.com/journals/fjme.htm Published by Pushpa Publishing house, Allahabad, India.

Weisstein, E. (2003). CRC Concise Ensyclopedia Mathematics. Chapman: CRC Press. 